\title{
What Explains Movements in the Peso/Dollar Exchange Rate?
}

$Y i W u$ 


\title{
IMF Working Paper
}

Western Hemisphere Department

\section{What Explains Movements in the Peso/Dollar Exchange Rate? Prepared by Yi Wu*}

Authorized for distribution by Ulric Erickson von Allmen

July 2013

\section{This Working Paper should not be reported as representing the views of the IMF. The views expressed in this Working Paper are those of the author and do not necessarily represent those of the IMF or IMF policy. Working Papers describe research in progress by the author(s) and are published to elicit comments and to further debate.}

\begin{abstract}
This paper examines the factors affecting the weekly peso/dollar exchange rate movements between 1999 and 2013 using an error correction model. The model fits the historical data well. While copper price is the most important determinant of the peso exchange rate over the long run, other factors including interest rate differential, global financial distress, local pension funds' derivative position, as well as the Federal Reserve's quantitative easing also affect the peso in the short run. The Central Bank of Chile's foreign exchange interventions in 2008 and 2011 had a small impact on the peso.
\end{abstract}

\section{JEL Classification Numbers:F31}

Keywords: Chilean peso, exchange rate

Author's E-Mail Address:ywu@imf.org

\footnotetext{
*I thank Ulric Erickson von Allmen, Jorge Chan-Lau, Fei Han, Charles Kramer, J. Daniel Rodriguez, Hui Tong, Shengzu Wang, seminar participants at the Central Bank of Chile, and in particular Diego Gianelli G., Philip Liu, and Li Zeng for very helpful comments and suggestions, and Matias Arnal for help with data. All errors are my own. The views expressed herein are those of the author and should not be attributed to the IMF, its Executive Board, or its management
} 


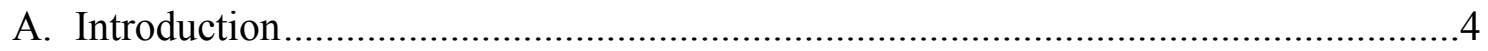

B. Possible Determinants of the Peso Exchange Rate................................... 9

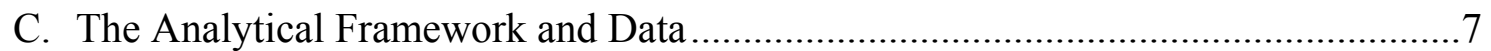

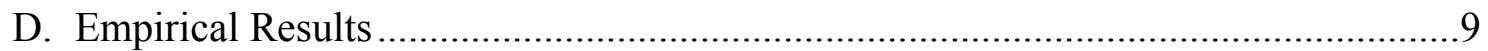

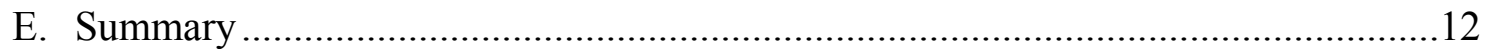

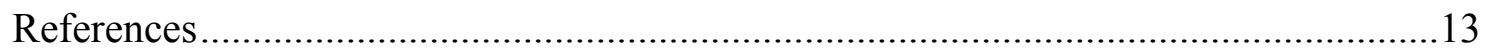

Figures

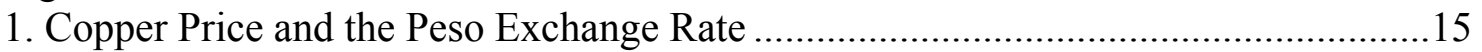

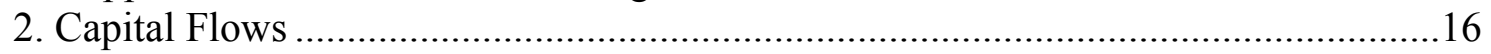

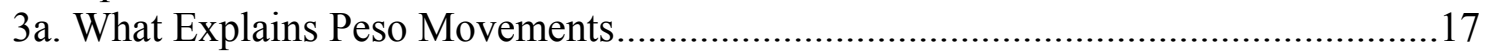

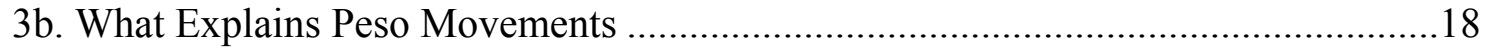

4. Actual vs. 3-Month Dynamic Simulation Forecast.....................................................19

Tables

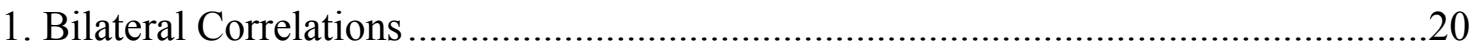

2. Exchange Rate Regressions: Long-run Dynamics.................................................20

3a. Exchange Rate Regressions: Short-run Dynamics...............................................21

3b. Exchange Rate Regressions: Short-run Dynamics ................................................22 


\section{A. Introduction}

1. The Chilean peso has historically moved closely with copper prices. In 2012, copper accounted for 54 percent of Chile's exports, 14 percent of fiscal revenue, and 13 percent of nominal GDP. The Chilean peso is one of the so-called "commodity currencies." While it is notoriously difficult to explain short-term exchange rate movements, the literature has established commodity prices as a robust and exogenous fundamental in explaining the behavior of the commodity currencies (Amano and van Norden, 1993; Cashin, Cespedes, and Sahay, 2004).

2. There are, however, episodes when the peso deviates from copper prices (Figure 1). One such episode began on June 2012: the peso appreciated almost 6 percent against the U.S. dollar (as of May 24) despite a small decline in copper prices. Notwithstanding the recent weakening of the peso (which is also a regional phenomenon), it still appears to be stronger than justified by copper prices. This raises the question what other factors also drive peso's movements. For example, there have been much public debate in Chile on the influence on the peso from monetary policy in advanced economies and capital flows (Larraín, 2013).

\section{This chapter seeks to explain the peso movements, using a simple error-}

correction model. The study uses weekly dollar/peso exchange rate data from October 1 , 1999, when the peso became floating, to May 24, 2013. Weekly data are used because some explanatory variables are only available on weekly basis and because it helps smooth the noisy daily exchange movements. The focus on the nominal exchange rate is because it is available at high frequency.

4. A number of past research examined the peso exchange rate. Cowan, Rappoport, and Selaive (2007) studied the determinants of peso-dollar exchange rate using daily data from 1993 to 2006. They found that copper and oil prices are important determinants of the long and short term dynamics of the peso, and changes in the pension funds' limits on foreign assets had small and transitory effects. Caputo, Núñez, and Valdés (2008) studied the peso real exchange rate using quarterly data. The Chilean peso is also often included in studies on commodity currencies (e.g., Chen and Rogoff, 2003 and 2012).

\section{Our model fits the in-sample exchange rate movements well, including for the} recent period. It finds that while copper price is the most important driver of peso exchange rate, accounting for the bulk of its long-run movements, other factors including interest rate differential, global financial distress, the Federal Reserve's quantitative easing (QE), and local pension funds' foreign exchange derivative position also affect the peso exchange rate in the short run. The strength of the peso since last June seems to be attributable to combination of factors, including the moderation in global financial risks and the QE. 
6. This chapter is organized as follows: Section B discusses possible determinants of the peso exchange rate; Section $\mathrm{C}$ discusses the framework and data for the empirical test; Section D presents the statistical results; and Section E provides some concluding remarks.

\section{B. Possible Determinants of the Peso Exchange Rate}

7. Strong capital inflows seem to have helped support peso. FDI and portfolio inflows, both gross and net, have increased substantially after the 2008/09 global financial crisis (Figure 2), along with a generally strengthening peso. Gross inflows reached historical high in 2012 with record FDI and portfolio inflows. While capital outflows also increased substantially in 2012 (in particular outward investment by Chilean pension funds, leading to decline in net inflows), net capital inflows improved sharply in the second half of the year, coinciding with the strengthening of the peso. It should also be noted that copper prices could affect capital inflows indirectly, e.g., through its impact on domestic demand.

8. Carry trade, one form of capital flows, may also have affected the peso. The main form of carry trade for nonresidents is through the foreign exchange forward market (ChanLau, 2009). ${ }^{1}$ These activities have been particularly volatile in recent months (see more in the next paragraph). Investors would use dollar (which has a lower interest rate) as the funding currency to invest in the peso, where they just hold a long peso position in the forward market, which would lead to a strengthening of the peso in the sport market. ${ }^{2}$ Chile's onshore forward market is deep with daily transactions averaging $\$ 5.0$ billion during January-April 2013. Transactions include both deliverable and non-deliverable forward, but the latter is more common. Average daily turnover at the offshore forward market (non-deliverable only) amounts to \$0.5-\$1 billion (HSBC, 2013). Chile's onshore spot market is one of Latin America's most liquid, with daily turnover averaged US\$4.4 billion during January-April 2013, and spot transactions can only be done onshore. Investors have also used the peso as the funding currency to invest in the Brazilian real (as interest rates are lower in Chile). In such a case, they would hold a short position in the peso in the forward market, which would weaken the peso in the spot market. ${ }^{3}$ But compared with carry traders using dollar as the funding currency, the former group appears to be dominant, at least in the recent period.

9. Carry trade seems to contribute to the peso's weakening since May. While carry traders using dollar as the funding currency would hold a short dollar position, nonresidents as a whole usually hold a net long position in dollar, suggesting that many positions are

\footnotetext{
${ }^{1}$ This is partially due to barriers for nonresidents to enter the local bond market. For example, registering to buy bonds in Chile takes about six months (Bloomberg, 2013).

${ }^{2}$ Domestic banks are the counterparty to these long peso positions in the onshore market, and they would sell dollar in the spot market to balance it, strengthening the peso in the spot market.

${ }^{3}$ These investors would hold simultaneous short peso positions vs. dollar and long positions in Brazilian real vs. dollar.
} 
probably for real hedging needs. However, between November 2012 and February 2013, nonresidents have substantially reduced their long dollar position (by $\$ 7.7$ billion in the onshore market, Figure 3a). This is consistent with an increase in carry trade with the peso as the target currency. By November the peso had already appreciated significantly and the subsequent appreciation was moderate. It therefore seems that the impact of carry trade on the peso's strength before May was probably moderate and "carry traders" were mostly "chasing" the peso's appreciation. ${ }^{4}$ Nonresidents subsequently dramatically reversed their positions, and their net long dollar positions reached $\$ 13.2$ billion by early June (up from \$2.7 billion in mid-April)-the highest since October 2008, when the data first became available. This reversal seems to have contributed to the peso's deprecation since May.

\section{Our model controls for interest differentials for the short-run peso dynamics, as the standard practice in the literature, instead of directly controlling for capital flows.} There are no direct data on carry trade, and capital flows data are only available on a monthly basis. In addition, estimates directly using capital flows could be more subject to the endogeneity problem. Some factors could by themselves lead to an appreciation of the peso and increased capital inflows, and there could be an endogeneity problem if these factors are not properly accounted for. Capital flows could also be endogenously responding to exchange rate movements. Interest differential is more likely to be exogenous: with the implementation of a full-fledged inflation targeting regime and a floating exchange rate in 1999, Chile's monetary policy has been mostly responding to inflation (and business cycles), instead of to exchange rate movements (Central Bank of Chile, 2007; McGettigan et al., 2013).

\section{Local institution investors also play an important role in determining the peso}

exchange rate. This is particularly the case for pension funds. Assets under management of Chilean pension funds amounted to $\$ 162$ billion at end-2012 (60 percent of GDP), with pension funds' oversea investment standing at $\$ 62$ billion. Movements of these assets can have a large impact on local capital markets and interest rate, as well as on the exchange rate. As required by Chilean regulations, pension funds need to hedge part of their oversea investments via holding short dollar positions (about US\$10.4 billion as of end-March 2013) in the onshore derivative market. ${ }^{5}$ As the hedging is required by regulation (there are also episodes of regulation changes), it can be considered largely exogenous. The data for pension funds' derivative position are only available from 2007 onward, it is therefore only included in the robustness checks.

\footnotetext{
${ }^{4}$ This could be a self-enforcing circle: the peso's appreciation may attract more long peso positions in the forward market, which would strengthen the peso in the spot market further. Granger causality tests do suggest that nonresidents' forward position and the peso exchange rate have predicting power over each other.

${ }^{5}$ Pension funds' net short dollar positions in the off-shore market were much smaller, at \$54 million at the same time. Ideally pension funds' net transactions in the spot market should also be controlled for, but these are not published (and relatively small).
} 
12. The model also accounts for other factors that may affect the peso including Federal Reserve's quantitative easing (QE) and global financial distress. The QE (November 2008-March 2010, November 2010-July 2011, and since September, 2012) could affect the dollar/peso exchange rate by affecting the interest rate differential (although the U.S. short-term interest rate has been close to zero since late 2008). They could also have impact on commodity prices, including copper. On top of these channels, the size of the Federal Reserve's balance sheet could have additional impact on the peso exchange rates, e.g., through capital flows and expectations. Our estimations therefore include the balance sheet size of the Federal Reserve and the Central Bank of Chile for the analysis of the shortrun dynamics of the exchange rate. The model also includes measures of global and local risks. Finally, since expectations play an important role in exchange rate movements (Dornbusch, 1976), ${ }^{6}$ we also include expected future GDP growth in the robustness checks (the data are only available from 2007).

13. We also conduct some simple analysis on the short-run effect of the two latest foreign exchange interventions by the Central Bank of Chile. We use dummy variables to capture the Central Bank's interventions in 2008 and 2011, when it conducted \$50 million daily dollar purchases in the spot market in both cases (fully sterilized). Studies of Chile's earlier intervention episodes (August 16, 2001-January 1, 2002 and October 10, 2002February 10, 2003, where the Central Bank sold dollars) found that the most important impact of intervention came from the announcement (De Gregorio and Tokman, 2004; Cowan, Rappoport, and Selaive, 2007). This also seems to be the case in 2011, when the peso weakened by $4 \frac{1}{2}$ percent against the U.S. dollar the day after the announcement, and depreciated $6 \frac{1}{2}$ percent in the first week (the peso subsequently quickly recovered). A simple dummy variable for the intervention won't be able to capture all the dynamics, but it would capture the average impact of the invention-while it is in place.

\section{The Analytical Framework and Data}

14. We use an error-correction model that is similar to what is used in other studies that addresses both the long-run and short-run dynamics of the exchange rate (e.g., Cowan, Rappoport, and Selaive, 2007; Helliwell et al., 2004; Moazzami and Anderson, 2003).

Long-run dynamics:

$\mathrm{EX}_{\mathrm{t}}=\alpha_{0}+\alpha_{l}$ Copper $_{\mathrm{t}}+\alpha_{l} \mathrm{Oil}_{\mathrm{t}}+\alpha_{3}$ Rel-CPI $_{\mathrm{t}}+\mathrm{e}_{\mathrm{t}}$,

where $\mathrm{EX}_{\mathrm{t}}$ is the logarithm of the nominal dollar/peso exchange rate, at end-week. All explanatory variables are weekly averages to help reduce endogeneity. The estimates

\footnotetext{
${ }^{6}$ Which is the reason that Chen, Rogoff, and Rossi (2010) find that commodity currency exchange rates have robust power in predicting global commodity prices, since they already incorporate expectations of future commodity prices.
} 
basically capture the contemporaneous effects. Copper denotes the logarithm of copper prices and Oil denotes the logarithm of oil prices. Chile is a net oil importer, ${ }^{7}$ and higher oil prices would lead to a deterioration of the terms of trade and thus a likely weakening of the peso. Rel-CPI represents the ratio of U.S. CPI index to that of Chile. Monthly CPI index is converted into weekly index by interpolation. $e_{t}$ denotes the error term.

Short-run dynamics:

$\Delta \mathrm{EX}_{\mathrm{t}}=\beta_{0}+\beta_{1} \Delta$ Copper $_{\mathrm{t}}+\beta_{2} \Delta$ Rel-CPI $_{\mathrm{t}}+\beta_{3} \Delta$ CHL-US $_{\mathrm{t}}+\beta_{4} \Delta$ BRA-CHL $_{\mathrm{t}}+\beta_{5} \Delta$ CDS-Chile $_{\mathrm{t}}+$ $\beta_{6} \Delta \mathrm{ESP}-\mathrm{DEU}_{\mathrm{t}}+\beta_{7} \Delta \mathrm{VIX}_{\mathrm{t}}+\beta_{8} \Delta \mathrm{FED}_{\mathrm{t}-9}+\beta_{9} \Delta \mathrm{BCCh}_{\mathrm{t}-9}+\beta_{10} \Delta$ Rel-stock $_{\mathrm{t}-9}+\beta_{11} \Delta{\text { Interve } 2008_{\mathrm{t}}+}+$ $\beta_{12} \Delta$ Interve $2011_{\mathrm{t}}+\beta_{13} \mathrm{EC}_{\mathrm{t}-1}+\varepsilon_{\mathrm{t}}$,

$\Delta$ denotes the first deference. The oil price is not included in the short-run specification because it turns out to be insignificant in the long-run specification as discussed below. $C H L$ US is the interest spread between the 90-day Chile and U.S. government bills-the 90-day government bill market is the most liquid in Chile. A higher spread is expected to attract more portfolio and carry trade inflows to Chile, and lead to a stronger peso. BRA-CHL is the difference of the 90-day Brazilian and Chilean government bill yields. This serves as a proxy for alternative investment opportunities for international investors in the region (or among emerging markets), or carry trade opportunities using peso as the funding currency. In both cases, a higher Brazil-Chile interest spread is expected to weaken the peso.

CDS-Chile represents 5-year sovereign credit default swap spread (CDS) for Chile. It measures the perceived risks of investing in Chilean securities. ESP-DEU is the interest spread between 10-year Spanish and German government bonds. It serves as a proxy for financial distress in Europe. VIX is the implied volatility of S\&P 500 index options, a common measure of global financial distress.

FED denotes the balance sheet size of the U.S. Federal Reserve (base money) in trillions of dollars. This would capture the impact of the QE on the peso exchange rate in additional to its impact through reducing U.S. interest rates. Unlike the case of interest differential, currency movements in response to monetary expansion need not be instantaneous, and may take place over a more prolonged period (Ghosh and Qureshi, 2013). We therefore used a two-month lag for the Fed's balance sheet (which yields the largest coefficient). BCCh denotes the balance sheet size of the Central Bank of Chile in trillions of pesos, also in 2month lag. The data for $B C C h$ are published for every eight days, which are converted into weekly data by interpolation.

Rel-stock is the ratio of Santiago stock exchange's IPSA index to the U.S. S\&P 500 index. Higher stock market returns are expected to lead to more portfolio inflows. Again a 2-month lag is used. Interve2008 and Interve2011 are dummies for the foreign exchange interventions by the Central Bank of Chile, which equal to one during April 14-December 12, 2008 and January 4-December 16, 2011, and zero otherwise. $E C_{t-1}$ is the lagged error-correction term. Finally, $\varepsilon_{t}$ denotes the error term. All the data are from the Bloomberg and the Central Bank of Chile.

\footnotetext{
${ }^{7}$ Oil imports accounted for 8 percent of total imports in 2012.
} 
15. Figures $3 \mathrm{a}$ and $3 \mathrm{~b}$ plot the peso exchange rate against the explanatory variables. Table 1 reports the bilateral correlations between all the variables in level. Most of the bilateral correlations are of expected sign. The correlation between the exchange rate and copper prices is 0.82 .

\section{Empirical Results}

16. Augmented Dickey-Fuller unit root tests (Dicky and Fuller, 1979) cannot reject the null hypothesis of unit root for most variables. A time trend is included in tests for the copper price, exchange rate, and balance sheet size of the Federal Reserve and the Central Bank of Chile. The lag length is selected by the Schwarz information criterion (Schwarz, 1978). The null of unit root cannot be rejected at the 5 percent level for the exchange rate, copper prices, the two central bank balance sheets, the three interest spreads, and the relative stock index.

17. The Johansen cointegration test (Johanse 1991, 1995) suggests that there exists a co-integration relationship between the peso exchange rate and copper prices. The test uses a lag length of 4 , and assumes an intercept but no trend in the cointegrating equation. The null hypothesis of no cointegration equation can be rejected at the 1 percent level, for either the trace test or the maximum eigenvalue test. The result is robust to different trend specifications and lag length, and to either nominal or real exchange rate, or the inclusion of oil prices.

\section{Long-run results:}

18. Copper prices can explain most of the peso exchange rate movements over the long run. Column (1) of Table 2 reports the OLS regression results with copper prices as the only explanatory variable. Variations in copper prices could account for 67 percent of variations in the peso exchange rate over the sample period. Column (2) also includes oil prices and relative U.S.-Chile CPI. Oil prices turn out to be positive, although not significant. This probably reflects the high correlation between oil and copper prices (0.96). The relative CPI is positive and significant as expected. Column (3) is the "benchmark" long-run specification, which excludes oil prices. The results suggest that a 10 percent increase in copper prices would strengthen the peso by 1.7 percent over the long term. This captures the full impacts of copper prices on the exchange rate, including through other channels, and is a bit larger than the estimate in Cowan, Rappoport, and Selaive (2007).

19. The long-run relationship between copper prices and the peso exchange rate is robust to different specifications. Column (4) reports the results using the dynamic OLS method developed by Stock and Watson (1993), and the results are similar. The dynamic OLS estimation simply adds leads and lags of differenced explanatory variables to a static cointegration regression so as to eliminate small-sample bias resulting from correlation between the error term and the explanatory variables. The reported regression includes 2 leads and lags, and the results are similar with alternative length of leads and lags. The coefficients for the leads and lags are not statistically significant and are not reported to save 
space. The error terms in the dynamic OLS procedure are, however, serially correlated. The standard errors are therefore estimated using the Newey and West (1987) adjustment with a lag length of up to 2. Column (5) reports the results using log real peso exchange rate (essentially imposing a unit coefficient on the relative CPI), where the coefficient for copper prices is slight larger. Column (6) reports the results for the sample ending at end-2011. Compared with the results reported in Column (3), the coefficient on copper prices is very close, while the coefficient for the error-correction term is a bit larger.

Short-run results:

20. Some other explanatory variables are also important in the short run. Column (1) of Table 3 a reports the short-run results including all explanatory variables, where the sample size is reduced to 2003 onward. Column (2) then only includes the significant variables: the Chile-U.S. interest differential, VIX, the central bank balance sheets, and the intervention dummies. The data are also available for the whole sample period. We also tried to include one lag of the explanatory variables and the results are reported in Column (3). The lagged variables are insignificant (not reported to save space) except for copper prices. Column (4) of Table 3a reports the results using the real peso-dollar exchange rate as the dependent variable. The results (for the significant variables) are broadly similar across Columns (1) to (4). All short-run regressions are based on corresponding long-run results reported in Table 2.

\section{The coefficient on the Chile-U.S. short-term interest is small, while the} coefficient on VIX is relatively large. A 100 basis points (bps) increase in the spread would only strengthen the peso by 0.4 percent against the dollar in the short run, using the results form Column (2), which is our benchmark short-run specification. ${ }^{8}$ Higher global financial distress, as measured by VIX, would weaken the peso, and the impact is relatively large: a one standard deviation increase in VIX (about 9) would weaken the peso by about 2 percent. The VIX has declined by 12 points between June 2012 and mid-March 2013, and subsequently rose 2 points.

\section{A larger balance sheet of the Federal Reserve is associated with a peso}

appreciation against the dollar in the short run. The Federal Reserve's balance sheet has increased by about $\$ 450$ billion since September 2012 when QE3 was introduced. The regression results suggest that this expansion would imply a strengthening of the peso by about 2 percent (although there will be a lag for the full impact). The expansion of the Federal Reserve's balance sheet during the height of the 2008/09 financial crisis and the subsequent QE (in particular QE2 and QE3) may be of different nature. To control for this possibility, we also added the interaction of the Fed's balance sheet and a dummy variable

\footnotetext{
${ }^{8}$ Level regression would yield a substantially larger coefficient. The Chile-U.S. interest differential is of the "wrong" sign in Cowan, Rappoport, and Selaive (2007).
} 
which equals to 1 after the implementation of QE1 or QE2. This term turns out to be insignificant in either case, while other results remain unchanged (results not reported).

\section{In contrast, a larger balance sheet of the Central Bank of Chile would weaken} the peso in the short run, everything else equal. In addition, the Central Bank's interventions in 2008 and 2011 seem to have a moderate impact on the exchange rate in the short run. The estimates suggest that the peso has been weakened by about $3 \frac{1}{2}$ and $2 \frac{1}{2}$ percent, by the two interventions, respectively. Finally, the other explanatory variables included in Column (1) are insignificant. ${ }^{9}$

In-sample forecasts:

\section{The model fits the in-sample peso exchange rate movements reasonably well.}

Figure 4 plots the actual dollar/peso exchange rate (in $\log$ ) vs. the 3 -month dynamic simulation forecast, using the coefficients from Column (3) of Table 2 and Colum (2) of Table 3a. The model's projections are based on dynamic simulations of equations (1) and (2), so the projected value at time $t$ is used to calculate the prediction at $t+1$, etc., over the next 3 months on a rolling basis. The forecast tracks the actual peso movements relatively well, including for the recent period. Finally, Colum (4) of Table 3a reports the results using the real dollar/peso exchange rate as the dependent variable. The results are very close to those of Column (2).

25. Forecasting using a shorter sample period yield very similar results. Column (1) of Table $2 \mathrm{~b}$ reports the results for the sub-sample ending in 2011. The result is pretty close to the baseline results, although the coefficient for the balance sheet of Central Bank of Chile becomes statistically insignificant. 3-month dynamic simulation forecast yield almost identical results as those shown in Figure 4.

Adding additional explanatory variables:

\section{We next add three additional explanatory variables to the short-run equation:}

U.S. nominal effective exchange rate. This variable is added to control for the possibility that the movements in the dollar/peso exchange rate simply reflects a U.S. dollar story. The data are only available on monthly basis (and up to March) and are converted into weekly data by interpolation.

Pension funds' short dollar forward position. This is the short forward dollar position held by the Chilean pension funds in the local foreign derivative market, in billions of dollars. The Central Bank publishes monthly data for 2007-08 and four observations each month since 2009. These are converted into weekly data by interpolation.

\footnotetext{
${ }^{9}$ We also used the average CDS of European banks to replace Spain-Germany spread as the measures of financial distress in Europe, which is also insignificant.
} 
Expected growth over the next 12 months. A better growth perspective is expected to lead to a stronger peso. The Central Bank publishes monthly survey to local economists on expected annual growth rate for the current and the next year. The expected growth over the next 12 months is derived, as a proxy, as the weighted average of the expected growth for the current and the next year, using the remaining months of the current year as the weight for the current year. The monthly data are then converted into weekly data by interpolation.

\section{The results are broadly similar with the baseline results for the original}

variables. Column (1) of Table $3 \mathrm{~b}$ reports the results including the U.S. nominal effective exchange rate as the additional explanatory variable. The U.S. nominal exchange rate is negative and significant as expected, while the coefficients for other variables are broadly similar to the benchmark specification, except that the relative CPI becomes statistically insignificant. Column (2) of Table 3b reports the results adding the pension's short dollar position and the expected GDP growth, where the sample size is substantially smaller. The pension's short dollar position is positive as expected and significant at the 1 percent level. The estimate suggests that an increase of local pension funds' short dollar position by $\$ 1$ billion would strengthen the peso by 0.4 percent against the dollar. The growth expectation turns out to be negative (although insignificant), even though it has a high positive simple correlation with the peso exchange rate (0.63). This may reflect the fact that the expected growth is highly correlated with copper prices (correlation 0.78 ) which is already included in the regression. The coefficients for other variables are broadly similar to the benchmark specification, except that the coefficient for the error correction term is a bit larger, and the Chile-U.S. interest rate spread becomes insignificant (p-value is 0.13 ).

\section{E. Summary}

\section{This chapter examines the weekly nominal dollar/peso exchange rate between October 1999 and May 2013 using an error-correction model. The model fits the} historical exchange rate data well. While copper prices can explain the bulk of peso movements over the long run, other factors also play an important role in the short run, including interest rate differential, global financial risks, and local pension funds' foreign exchange derivative position. The $\mathrm{QE}$ also seems to lead to a strengthening of the peso. The analysis finds that the Central Bank of Chile's foreign exchange interventions in 2008 and 2011 had a small impact on the peso. 


\section{REFERENCES}

Amano, Robert, and Simon van Norden, 1993, "A Forecasting Equation for the Canada-U.S. Dollar Exchange Rate," in The Exchange Rate and the Economy, Bank of Canada.

Bloomberg, 2013, “Bernanke-Fueled Rout Avoided by Unwelcoming Chile,” June 5.

Caputo, R., M. Núñez, and R.O. Valdés, 2008, "Análisis del Tipo de Cambio en la Práctica," Economía Chilena, April, Central Bank of Chile.

Cashin, Paul, Luis F. Cespedes, and Ratna Sahay, 2004, "Commodity Currencies and the Real Exchange Rate,” Journal of Development Economics, Vol. 75, pp.239-268.

Central Bank of Chile, 2007, "Monetary Policy in an Inflation Targeting Framework."

Chan-Lau, Jorge, 2007, "Foreign Exchange Hedging in Chile," Derivatives Use, Trading and Regulation, Vol. 12 (3), pp.250-267.

Chen, Yu-Chin, and Kenneth Rogoff, 2003, "Commodity Currencies," Journal of International Economics, Vol. 60 (1), pp.133-160. , 2012, “Are Commodity Currencies an Exception to the Rule?" Journal of Global Economics, Vol. 1 (1).

Chen, Yu-Chin, Kenneth Rogoff, and Barbara Rossi, 2010, "Can Exchange Rates Forecast Commodity Prices?” Quarterly Journal of Economics, Vol. 125, pp.1145-1194.

Cowan, Kevin, David Rappoport, and Jorge Selaive, 2007, "High Frequency Dynamics of The Exchange Rate in Chile," Central Bank of Chile Working Paper 433.

De Gregorio, José, and Andrea Tokman R, "Flexible exchange rate regime and forex intervention," Bank for International Settlements Paper 24.

Dickey, D.A. and W.A. Fuller, 1979, "Distribution of Estimators for Autoregressive Time Series with a Unit Root," Journal of American Statistical Association, Vol. 74, pp.427431.

Dornbusch, Rudiger, 1976, “Expectations and Exchange Rate Dynamics," Journal of Political Economy, Vol. 84, pp.1161-1176.

Ghosh, Atish R., and Mahvash S. Qureshi, 2013, "Thinking About Exchange Rates in a World of High Capital Mobility: What We Have Learned in the Past Thirty Years," International Monetary Fund, memo.

HSBC, 2013, "HSBC’s Emerging Markets Currency Guide 2013.”

Helliwell, John, Ramzi Issa, Robert Lafrance, and Qiao Zhang, 2004, "NEMO: An Equation for the Canadian Dollar," Bank of Canada. 
Johansen, Soren, 1991, "Estimation and Hypothesis of Cointegration Vectors in Gaussian Vector Autoregression Models," Econometrica, Vol. 59, pp.1551-1580.

, 1995, Likelihood-based Inference in Cointegrated Vector Autoregressive Models Oxford and New York, Oxford University Press.

Larraín, Felipe, 2013, “QE takes a toll on emerging economies,” Financial Times, February 3.

Moazzami, B, and F.J. Anderson, 2003, "Long-term Trend and Short-run Dynamics of the Canadian Dollar: An Error Correction Modeling Approach," Applied Economics, Vol. 35, pp.1527-1530.

Donal McGettigan, Kenji Moriyama, J. Noah Ndela Ntsama, Francois Painchaud, Haonan Qu, and Chad Steinberg, 2013, "Monetary Policy in Emerging Markets: Taming the Cycle," International Monetary Fund working paper, forthcoming.

Newey, Whitney K. and Kenneth D. West, 1987, “A Simple Positive Semi-Definite Heteroscedasticity and Autocorrelation Consistent Covariance Matrix." Econometrica, 55: 703-8.

Stock, J. H., and M. W. Watson, 1993, “A Simple Estimator of Cointegrating Vectors in Higher Order Integrated Systems," Econometrica, Vol. 61(4): 783-820. 
Figure 1. Copper Price and the Peso Exchange Rate

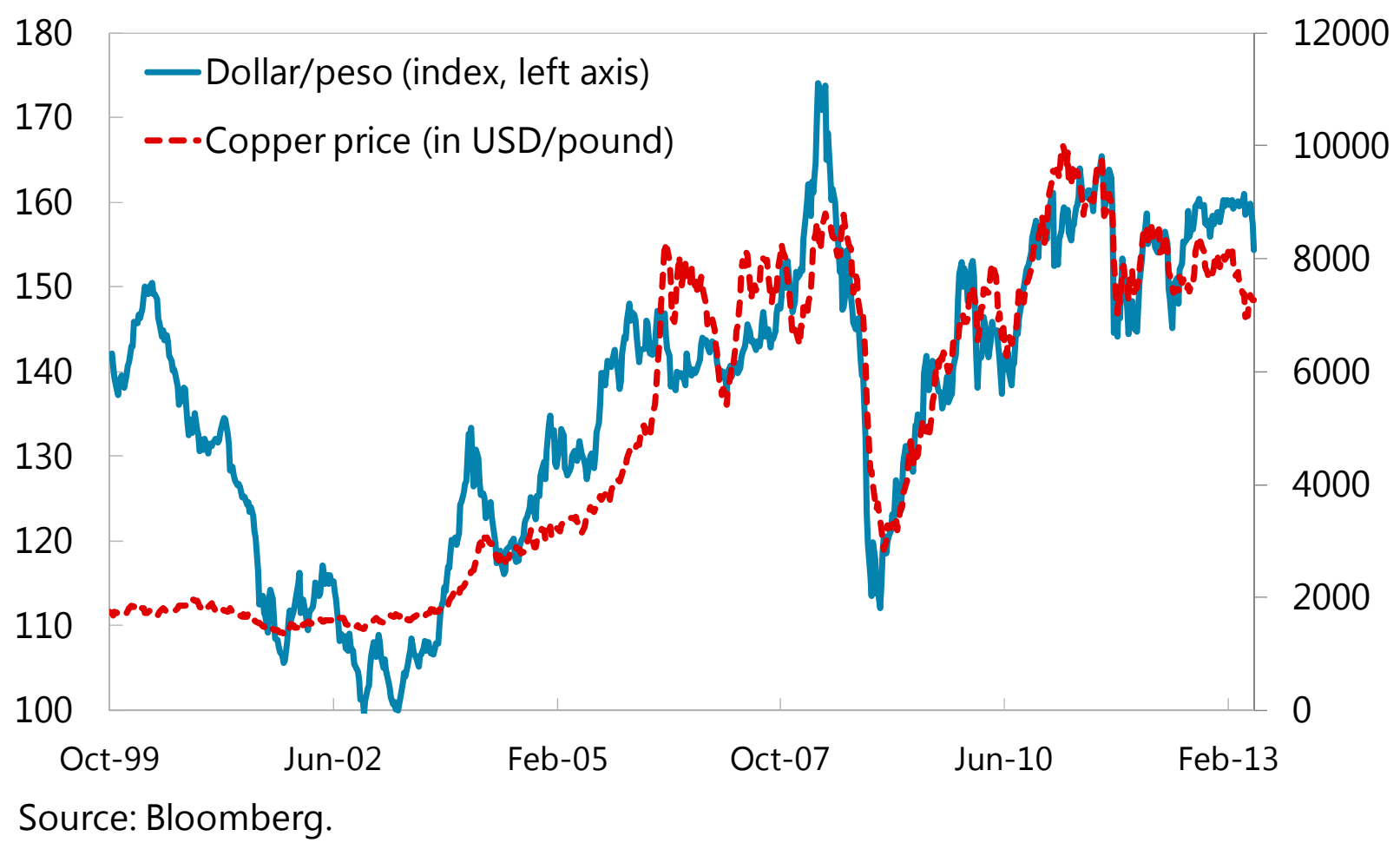


Figure 2. Capital Flows
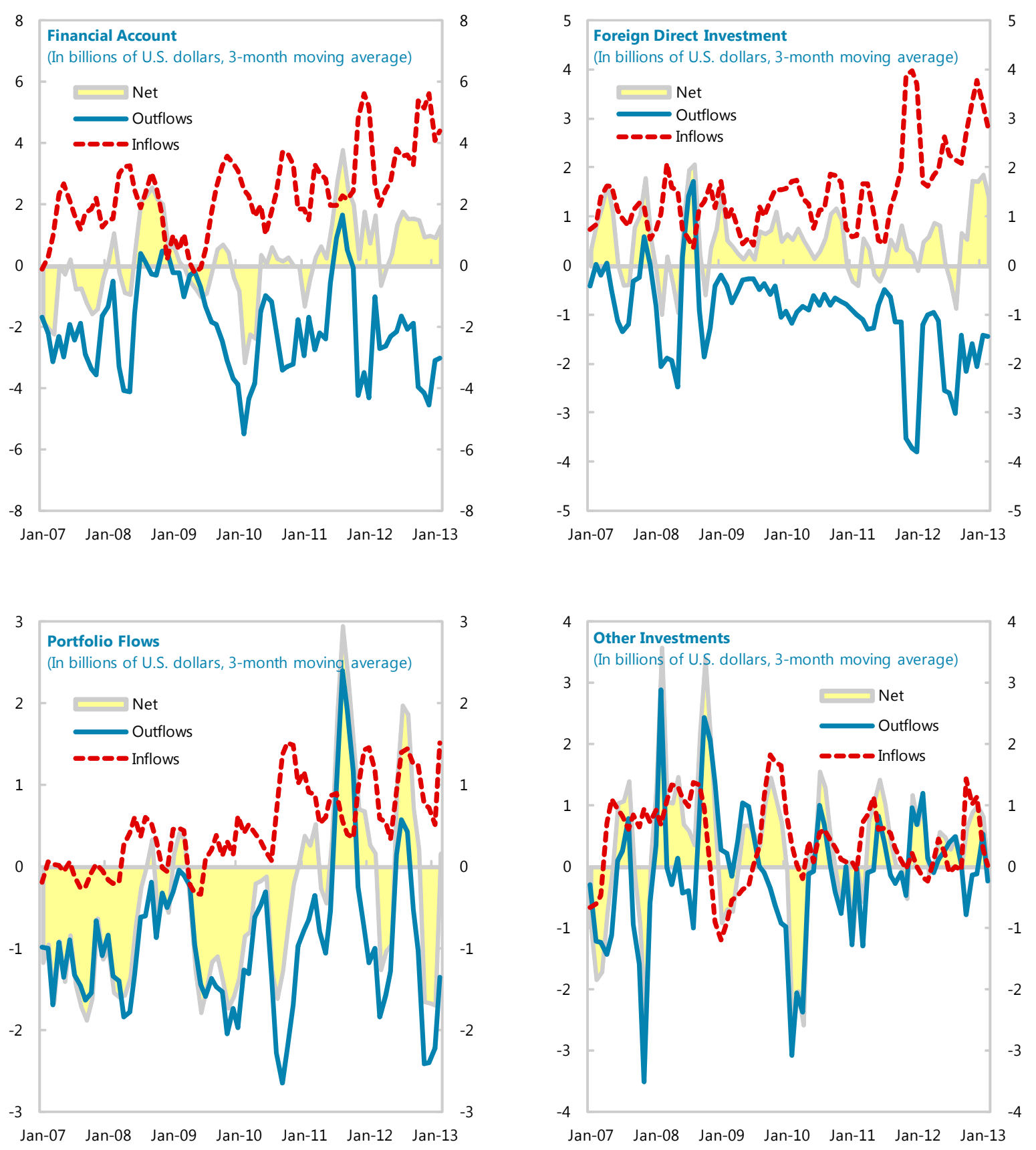

Source: Central Bank of Chile. 
Figure 3a. What Explains Peso Movements
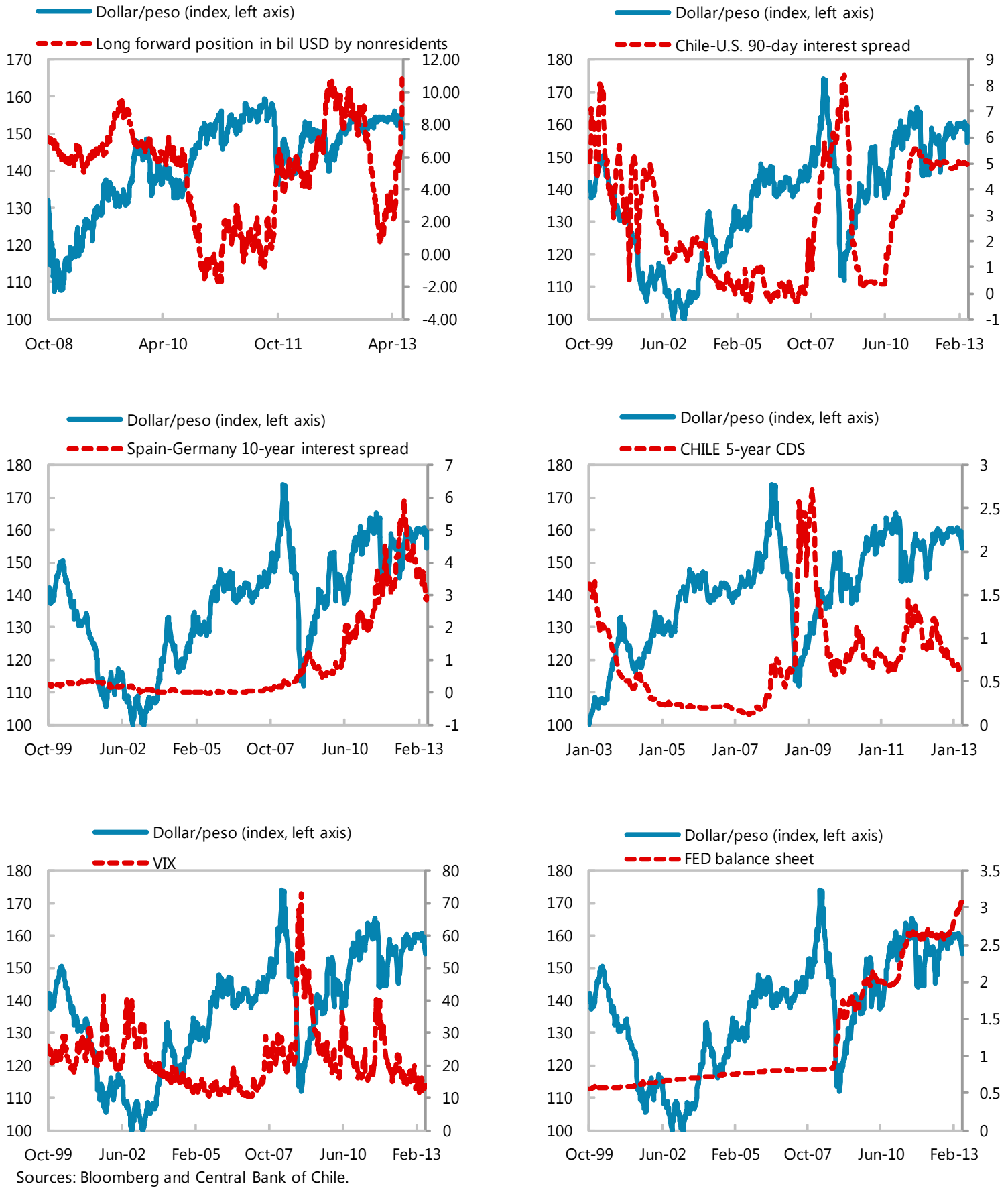

Sources: Bloomberg and Central Bank of Chile. 
Figure 3b. What Explains Peso Movements
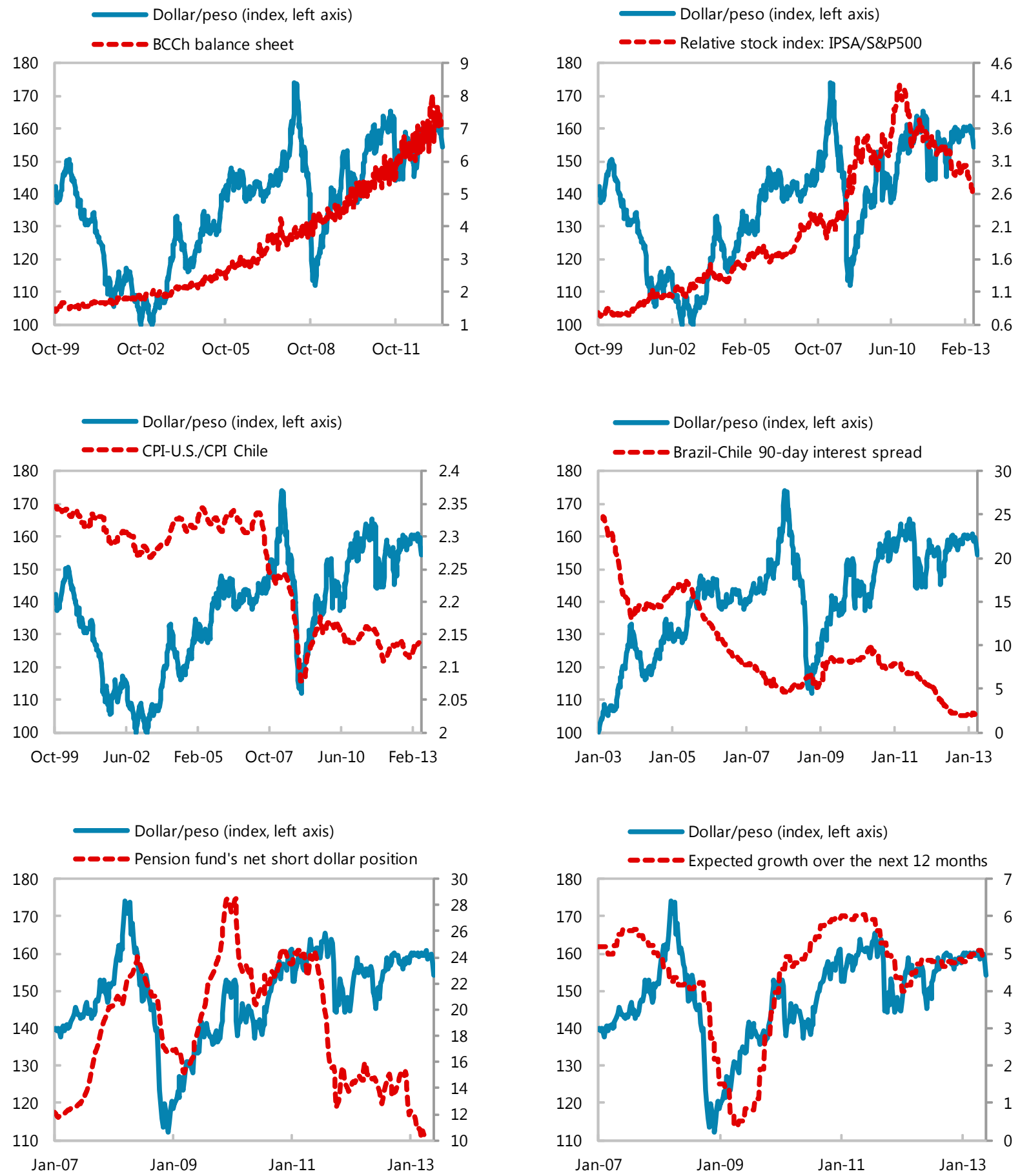

Sources: Bloomberg and Central Bank of Chile. 
Figure 4. Actual vs. 3-Month Dynamic Simulation Forecast

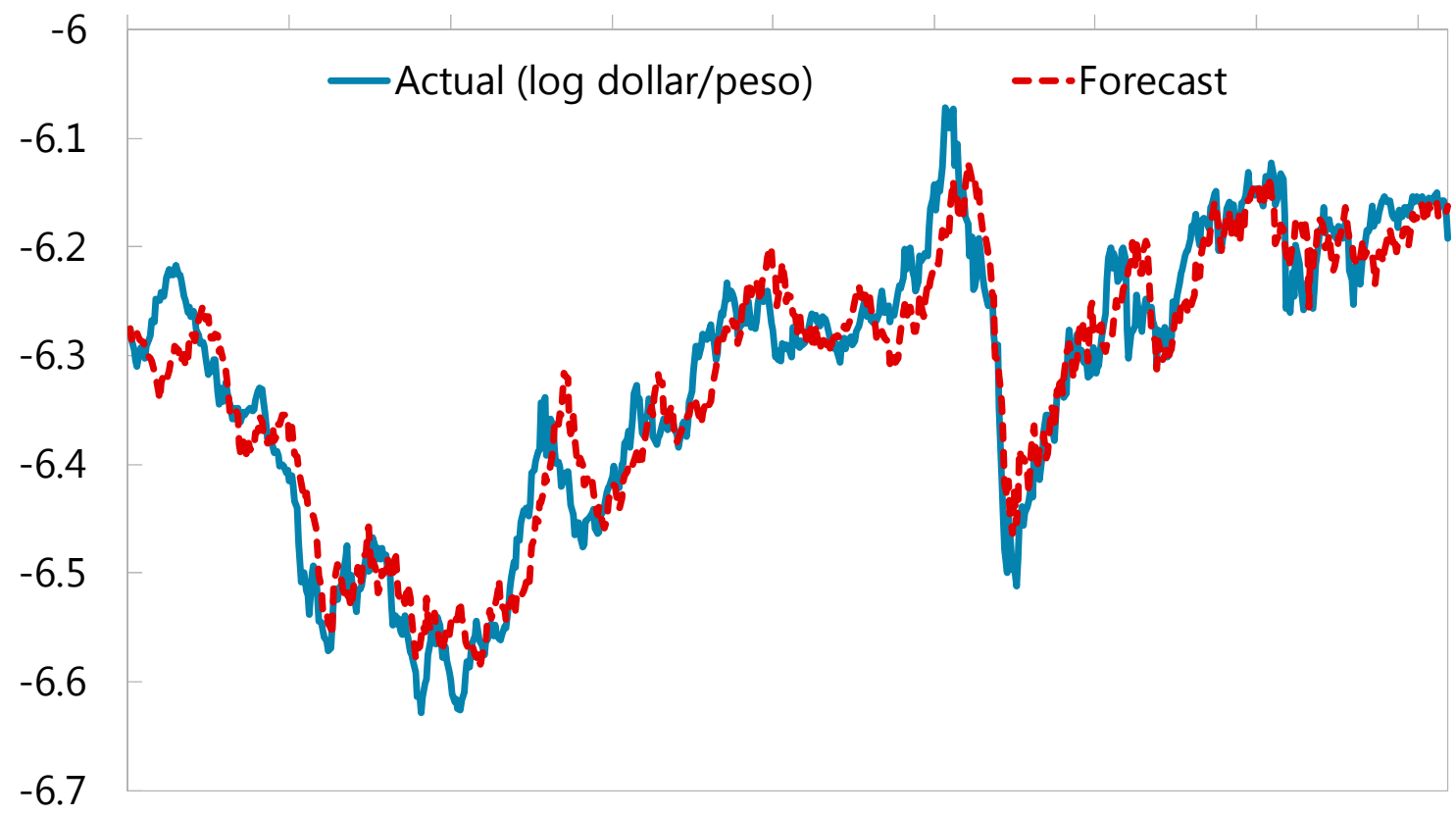

Oct-99 Jun-01 Feb-03 Oct-04 Jun-06 Feb-08 Oct-09 Jun-11 Feb-13 Source: Fund staff calculations. 
Table 1. Bilateral correlations

\begin{tabular}{|c|c|c|c|c|c|c|c|c|c|c|c|c|c|}
\hline & & & Chile-U.S. & ESP-DEU & & & & & IPSA/ & & BRA-CHL & & \\
\hline & $\begin{array}{l}\text { Dollar } \\
\text { /Peso }\end{array}$ & Copper & $\begin{array}{c}\text { interest } \\
\text { spread }\end{array}$ & $\begin{array}{c}\text { interest } \\
\text { spread }\end{array}$ & $\begin{array}{l}\text { Chile } \\
\text { CDS }\end{array}$ & VIX & FED & $\mathrm{BCCh}$ & $\begin{array}{l}S \& P \\
500\end{array}$ & $\begin{array}{l}\text { CPI-US/ } \\
\text { CPI-Chile }\end{array}$ & $\begin{array}{c}\text { interest } \\
\text { spread }\end{array}$ & $\begin{array}{l}\text { Pension } \\
\text { funds }\end{array}$ & $\begin{array}{c}\text { Expected } \\
\text { growth }\end{array}$ \\
\hline \multicolumn{14}{|l|}{ Dollar/Peso } \\
\hline Copper & 0.82 & & & & & & & & & & & & \\
\hline Chile-U.S. interest spread & 0.24 & -0.01 & & & & & & & & & & & \\
\hline Spain-Germany interest spread & 0.52 & 0.52 & 0.47 & & & & & & & & & & \\
\hline Chile CDS & -0.27 & -0.17 & 0.56 & 0.34 & & & & & & & & & \\
\hline VIX & -0.31 & -0.22 & 0.43 & 0.01 & 0.82 & & & & & & & & \\
\hline FED balance sheet (2-month lag) & 0.59 & 0.67 & 0.31 & 0.91 & 0.36 & 0.01 & & & & & & & \\
\hline BCCh balance sheet (2-month lag) & 0.69 & 0.81 & 0.32 & 0.86 & 0.30 & -0.01 & 0.95 & & & & & & \\
\hline IPSA/S\&P 500 (2-month lag) & 0.63 & 0.87 & 0.07 & 0.64 & 0.32 & 0.02 & 0.83 & 0.90 & & & & & \\
\hline CPI-US/CPI-Chile & -0.42 & -0.61 & -0.40 & -0.75 & -0.68 & -0.37 & -0.86 & -0.87 & -0.84 & & & & \\
\hline Brazil-Chile interest spread & -0.80 & -0.85 & -0.56 & -0.60 & -0.12 & -0.17 & -0.63 & -0.80 & -0.75 & 0.64 & & & \\
\hline Pension funds' short dollar position & 0.10 & 0.10 & -0.19 & 0.35 & 0.22 & -0.06 & 0.67 & 0.44 & 0.88 & -0.06 & 0.38 & & \\
\hline Expected growth over next 12 months & 0.63 & 0.78 & 0.05 & 0.25 & -0.62 & -0.54 & 0.15 & 0.25 & 0.05 & 0.30 & -0.06 & -0.16 & \\
\hline U.S. nominal effective exchange rate & -0.82 & -0.95 & -0.12 & -0.54 & 0.01 & 0.12 & -0.70 & -0.84 & -0.88 & 0.67 & 0.67 & -0.12 & -0.54 \\
\hline
\end{tabular}

Note: Exchange rate, copper prices, and relative stock and CPI indices are in logarithm.

Table 2. Exchange Rate Regressions: Long-run Dynamics

\begin{tabular}{|c|c|c|c|c|c|c|}
\hline $\log (\$ /$ peso $)$ & Nominal & Nominal & Nominal & Nominal & Real & Nominal \\
\hline Sample period & $\begin{array}{c}1999 / 10- \\
2013 / 5\end{array}$ & $\begin{array}{c}1999 / 10- \\
2013 / 4\end{array}$ & $\begin{array}{c}1999 / 10- \\
2013 / 4\end{array}$ & $\begin{array}{c}1999 / 10- \\
2013 / 4\end{array}$ & $\begin{array}{c}1999 / 10- \\
2013 / 4\end{array}$ & $\begin{array}{c}1999 / 10- \\
2011 / 12\end{array}$ \\
\hline Methodology & $\begin{array}{l}\text { OLS } \\
(1)\end{array}$ & $\begin{array}{c}\text { OLS } \\
(2)\end{array}$ & $\begin{array}{l}\text { OLS } \\
(3)\end{array}$ & $\begin{array}{c}\text { DOLS } \\
(4)\end{array}$ & $\begin{array}{l}\text { OLS } \\
(5)\end{array}$ & $\begin{array}{c}\text { OLS } \\
(6)\end{array}$ \\
\hline Log(copper prices) & $\begin{array}{c}0.158 * * * \\
(0.004)\end{array}$ & $\begin{array}{c}0.149 * * * \\
(0.015)\end{array}$ & $\begin{array}{c}0.171 * * * \\
(0.005)\end{array}$ & $\begin{array}{c}0.175 * * * \\
(0.009)\end{array}$ & $\begin{array}{c}0.191 * * * \\
(0.004)\end{array}$ & $\begin{array}{c}0.169 * * * \\
(0.005)\end{array}$ \\
\hline Log (oil prices) & & $\begin{array}{c}0.032 \\
(0.020)\end{array}$ & & & & \\
\hline CPI-US/CPI-Chile & & $\begin{array}{c}0.418 * * * \\
(0.095)\end{array}$ & $\begin{array}{c}0.388 * * * \\
(0.094)\end{array}$ & $\begin{array}{c}0.413 * * * \\
(0.139)\end{array}$ & & $\begin{array}{c}0.633 * * * \\
(0.102)\end{array}$ \\
\hline R-squared & 0.67 & 0.67 & 0.67 & 0.74 & 0.74 & 0.65 \\
\hline No. of obs & 713 & 709 & 709 & 704 & 709 & 640 \\
\hline
\end{tabular}

Note: Newey and West standard errors for dynamic OLS (DOLS).***, and *** denotes significant at

10,5 , and $1 \%$, respectively. 
Table 3a. Exchange Rate Regressions: Short-run Dynamics

\begin{tabular}{|c|c|c|c|c|}
\hline Dep. variable: $\log ($ dollar/peso $)$ & $\begin{array}{l}\text { Nominal } \\
2003 / 1-\end{array}$ & $\begin{array}{l}\text { Nominal } \\
1999 / 10-\end{array}$ & $\begin{array}{l}\text { Nominal } \\
1999 / 10-\end{array}$ & $\begin{array}{c}\text { Real } \\
1999 / 10\end{array}$ \\
\hline Sample period & $\begin{array}{l}2013 / 4 \\
(1)\end{array}$ & $\begin{array}{l}2013 / 4 \\
(2)\end{array}$ & $\begin{array}{l}2013 / 4 \\
(3)\end{array}$ & $\begin{array}{l}2013 / 4 \\
(4)\end{array}$ \\
\hline$\Delta \log ($ copper prices $)$ & $\begin{array}{l}0.121 * * * \\
(0.019)\end{array}$ & $\begin{array}{c}0.107 * * * \\
(0.017)\end{array}$ & $\begin{array}{c}0.100 * * * \\
(0.018)\end{array}$ & $\begin{array}{l}0.107 * * * \\
(0.017)\end{array}$ \\
\hline$\Delta \log ($ copper prices $)$, lag & & & $\begin{array}{c}0.043 * * * \\
(0.018)\end{array}$ & \\
\hline$\Delta$ CPI-US/CPI-Chile & $\begin{array}{l}1.296 * * * \\
(0.532)\end{array}$ & $\begin{array}{l}1.131 * * * \\
(0.475)\end{array}$ & $\begin{array}{l}1.692 * \\
(0.919)\end{array}$ & \\
\hline$\Delta$ Chile-U.S. 90-day interest spread & $\begin{array}{c}0.005 \\
(0.004)\end{array}$ & $\begin{array}{c}0.004 * * \\
(0.002)\end{array}$ & $\begin{array}{c}0.004^{* * *} \\
(0.002)\end{array}$ & $\begin{array}{c}0.004 * * \\
(0.002)\end{array}$ \\
\hline Braze-Chile 90-day interest spread & $\begin{array}{l}-0.003 \\
(0.003)\end{array}$ & & & \\
\hline Chile 5-year CDS spread & $\begin{array}{c}0.002 \\
(0.008)\end{array}$ & & & \\
\hline $\begin{array}{l}\Delta \text { Spain-Germany } 10 \text {-year interest } \\
\text { spread }\end{array}$ & $\begin{array}{l}-0.005 \\
(0.004)\end{array}$ & & & \\
\hline$\Delta \mathrm{VIX}$ & $\begin{array}{c}-0.002 * * * \\
(0.0003)\end{array}$ & $\begin{array}{c}-0.002 * * * \\
(0.0002)\end{array}$ & $\begin{array}{c}-0.002 * * * \\
(0.0002)\end{array}$ & $\begin{array}{c}-0.002 * * * \\
(0.0002)\end{array}$ \\
\hline$\Delta$ FED balance sheet (2-month lag) & $\begin{array}{c}0.050 * * * \\
(0.021)\end{array}$ & $\begin{array}{c}0.050 * * * \\
(0.020)\end{array}$ & $\begin{array}{c}0.047 * * \\
(0.021)\end{array}$ & $\begin{array}{c}0.052 * * * \\
(0.020)\end{array}$ \\
\hline $\begin{array}{l}\triangle \mathrm{BCCh} \text { balance sheet (2-month } \\
\text { lag) }\end{array}$ & $\begin{array}{l}-0.005 * \\
(0.003)\end{array}$ & $\begin{array}{l}-0.005^{*} \\
(0.003)\end{array}$ & $\begin{array}{c}-0.006^{* *} \\
(0.003)\end{array}$ & $\begin{array}{l}-0.005^{*} \\
(0.003)\end{array}$ \\
\hline$\Delta$ IPSA/S\&P 500 (2-month lag) & $\begin{array}{l}-0.005 \\
(0.030)\end{array}$ & & & \\
\hline$\Delta$ Intervention 2008 & $\begin{array}{c}-0.035 * * * \\
(0.009)\end{array}$ & $\begin{array}{c}-0.036 * * * \\
(0.009)\end{array}$ & $\begin{array}{c}-0.038 * * * \\
(0.009)\end{array}$ & $\begin{array}{c}-0.036 * * * \\
(0.009)\end{array}$ \\
\hline$\Delta$ Intervention 2011 & $\begin{array}{c}-0.023 * * * \\
(0.009)\end{array}$ & $\begin{array}{c}-0.025 * * * \\
(0.009)\end{array}$ & $\begin{array}{c}-0.027 * * * \\
(0.009)\end{array}$ & $\begin{array}{c}-0.025 * * * \\
(0.009)\end{array}$ \\
\hline Error correction term & $\begin{array}{c}-0.027 * * * \\
(0.011)\end{array}$ & $\begin{array}{c}-0.017 * * * \\
(0.007)\end{array}$ & $\begin{array}{c}-0.016 * * * \\
(0.007)\end{array}$ & $\begin{array}{l}-0.015 * * * \\
(0.006)\end{array}$ \\
\hline $\begin{array}{l}\text { R-squared } \\
\text { No. of obs }\end{array}$ & $\begin{array}{c}0.33 \\
535\end{array}$ & $\begin{array}{l}0.27 \\
708\end{array}$ & $\begin{array}{l}0.28 \\
707\end{array}$ & $\begin{array}{c}0.26 \\
708\end{array}$ \\
\hline
\end{tabular}

Note: $* * *$, and $* * *$ denotes significant at 10,5 , and $1 \%$, respectively. 
Table 3b. Exchange Rate Regressions: Short-run Dynamics

Dep. variable: $\log ($ dollar/peso), nominal

Sample period

$\begin{array}{ccc}1999 / 10- & 1999 / 10- & 2007 / 1- \\ 2011 / 12 & 2013 / 3 & 2013 / 3\end{array}$

(1)

(2)

(3)

$\Delta \log ($ copper prices $)$

$0.102 * * *$

$0.096 * * *$

$0.131 * * *$

(0.018)

(0.018)

(0.025)

$\triangle$ CPI-US/CPI-Chile

$1.169 * *$

0.621

$1.377 * *$

(0.503)

(0.494)

(0.665)

$\Delta$ Chile-U.S. 90-day interest spread

$0.004 * *$

$0.004 * *$

0.005

(0.002)

(0.002)

(0.003)

$\Delta \mathrm{VIX}$

$-0.002 * * *$

$-0.002 * * *$

$-0.002 * * *$

$(0.0002)$

(0.0002)

$(0.0003)$

$\triangle$ FED balance sheet (2-month lag)

$0.049 * *$

$0.052 * * *$

$0.046 * *$

(0.022)

(0.020)

(0.022)

$\triangle \mathrm{BCCh}$ balance sheet (2-month lag)

$-0.004$

$-0.005^{*}$

$-0.006^{*}$

(0.004)

(0.003)

(0.003)

$\Delta$ Intervention 2008

$$
\begin{gathered}
-0.036 * * * \\
(0.010)
\end{gathered}
$$

$-0.035 * * *$

(0.009)

$-0.036 * * *$

$-0.024 * * *$

$-0.026 * * *$

(0.010)

$\Delta$ Intervention 2011

(0.009)

(0.009)

$-0.026 * * *$

(0.010)

U.S. nominal effective exchange rate

$-0.575 * * *$

$-0.362$

(0.167)

(0.248)

Pension funds' short forward dollar

position

$0.004 * *$

(0.002)

Expected growth over the next 12 months

$-0.006$

(0.005)

Error correction term

$$
\begin{array}{cc}
-0.017 * * * & -0.012 * * \\
(0.007) & (0.006)
\end{array}
$$

$-0.034 * *$

(0.015)

R-squared

0.26

0.28

0.41

No. of obs

639

703

324

Note: $* * *$, and $* * *$ denotes significant at 10,5 , and $1 \%$, respectively. 